\title{
ANALISIS KEGIATAN SABTU LITERASI TERHADAP KETERAMPILAN MENULIS TEKS NARASI SISWA KELAS V SD MUHAMMADIYAH 3 SURABAYA DI MASA PANDEMI COVID-19
}

\author{
Abdul Muizz' ${ }^{1}$, Lilik Binti Mirnawati ${ }^{2}$, Ishmatun Naila ${ }^{3}$ \\ ${ }^{1}$ Universitas Muhammadiyah Surabaya \\ e-mail : abdul.muizz-2020@fkip.um-surabaya.ac.id \\ 2Universitas Muhammadiyah Surabaya \\ e-mail : lilikbintimirnawati@fkip.um-surabaya.ac.id \\ ${ }^{3}$ Universitas Muhammadiyah Surabaya \\ e-mail: ishmatun@fkip.um-surabaya.ac.id
}

\begin{abstract}
Abstrak
Tujuan dari penelitian ini adalah untuk mendeskripsikan bagaimana kegiatan sabtu literasi terhadap keterampilan menulis teks narasi siswa kelas V SD Muhammadiyah 3 Surabaya di masa pandemi. Yang mana penelitian ini merupakan penelitian kualitatif deskriptif dengan data yang diperoleh dari beberapa sumber, antara lain : Guru Kelas V, Pustakawan, dan Siswa kelas V. Teknik yang digunakan dalam penelitian ini yaitu observasi partisipan, wawancara tak terstruktur, dan dokumentasi. Teknik analisis data yang digunakan adalah model Miles dan Huberman yang terdiri dari reduksi data, sajian data, dan kesimpulan. Hasil penelitian ini, yaitu Sabtu Literasi merupakan suatu kegiatan literasi yang dilaksanakan pada hari Sabtu, yang berdurasi 45 menit. Siswa diminta untuk membaca teks bacaan narasi bentuk pdf, kemudian menceritakan kembali dalam bentuk tulisan. Selain itu, kegiatan ini bermanfaat dalam menambah keterampilan menulis teks narasi mereka, dan kegiatan sabtu literasi secara daring ini layak untuk digunakan dalam masa pandemi
\end{abstract}

Kata kunci: sabtu literasi, teks narasi, daring

\begin{abstract}
The purpose of this study is to describe how literacy Saturday activities affect the skills of writing narrative texts for fifth grade students at SD Muhammadiyah 3 Surabaya during the pandemic. This research is a qualitative descriptive study with data obtained from several sources, including: The Fifth Grade Teachers, Librarians, and Students of The Fifth Grade. The techniques used in this research are participant observation, unstructured interviews, and documentation. The data analysis technique used is the Miles and Huberman model which consists of data reduction, data presentation, and conclusions. The results of this study, namely Saturday Literacy is a literacy activity carried out on Saturdays, which lasts 45 minutes. Students are asked to read the narrative text in pdf form, then retell it in written form. In addition, this activity is useful in increasing their narrative text writing skills, and this bold literacy Saturday activity is suitable for use during a pandemic.
\end{abstract}

Keywords: saturday literacy, narration text, daring

Pendahuluan

Pendidikan adalah usaha sadar

dan terencana untuk mewujudkan suasana belajar dan proses

pembelajaran agar peserta didik secara aktif mengembangkan potensi dirinya untuk memiliki kekuatan spiritual keagamaan, pengendalian diri, kepribadian, kecerdasan, akhlak mulia, serta keterampilan yang diperlukan dirinya, masyarakat, bangsa dan negara (Undang-Undang Indonesia Nomor 20 Tahun 2003 Tentang Sistem Pendidikan Nasional, n.d.:3). Sehingga pendidikan 
mempunyai peranan penting dalam dilaksanakan dengan cara meningkatkan membentuk karakter dengan budaya membaca, menulis, dan menggunakan potensi diri yang ada untuk berhitung bagi seluruh warga masyarakat menghasilkan masyarakat yang kususnya dalam lingkup akademik. berkualitas dan berwawasan. Sehingga Dalam kurikulum 2013 kegiatan melalui pendidikan terutama didalam membaca, menulis dan berhitung dikenal proses pembelajaran, peserta didik turut aktiv mengembangkan potensi yang dimiliki.

Menurut Yudhistira bahwa berbicara mengenai pendidikan, pendidikan tidak akan berhasil jika tidak ada proses pembelajaran. Pembelajaran (learning) merupakan kunci keberhasilan pendidikan, karena inti dari pendidikan tiada lain adalah di pembelajaran (core of education is learning). Baik buruknya kualitas pendidikan sangat bergantung pada mutu pembelajran yang dikelola oleh guru. Pendidikan yang bermutu bersumber atau berpangkal dari mutu pembelajaranyang berkualitas yang dikelola oleh guru profesional (Safitri, 2009:1)

\section{Berdasarkan}

Peraturan

Pemerintah Nomor 19 Tahun 2005 Bab IV Pasal 21 ayat (2) tentang Standar Proses bahwa pelaksanaan proses pembelajaran dilaksanakan dengan mengembangkan budaya membaca dan menulis. Hal tersebut didukung dengan adanya Undang-undang Sisdiknas No 20 tahun 2003 Bab III Pasal 4 ayat 5 yang menyatakan bahwa pendidikan dapat dengan istilah literasi.

Menulis merupakan salah satu keterampilan berbahasa yang bersifat produktif dikarenakan penulis menuangkan ide, gagasan, pendapat, pengalaman, kritik, dan saran melalui paragraph yang berisi rangkaian kata-kata sehingga membentuk teks yang dapat dibaca. Dengan begitu menulis merupakan suata kegiatan yang kompleks. Menurut Hastuti, menulis merupakan proses yang kompleks karena memerlukan cara berpikir yang teratur dan memenuhi persyaratan penulisan, antara lain: 1) kesatuan gagasan yang ditulis, 2) kalimat yang digunakan harus jelas dan efektif, 3) paragraph disusun dengan baik, 4) tulisan harus disesuaikan dengan kadidah ejaan yang benar, dan 5) kosa kata yang dimiliki harus memadai (Tantri \& Dewantara, 2017:1).

Dengan gemar membaca siswa itu semakin banyak penguasaan kosakata/ perbendaharaan kata yang dimilikinya (Sunarti, 2020:1). Dengan demikian siswa dapat dikatakan mampu menguasai perbendaharaan kata. Sehingga kegiatan literasi terutama dalam membaca sangat 
erat kaitannya dengan menulis, seperti yang disebutkan bahwa keterampilan membaca sangat erat hubungannya dengan keterampilan menulis, semakin banyak dan baik dalam membaca maka karya tertulisnya juga semakin baik (Rinawati et al., 2020:1). Berdasarkan hasil analisis dalam penelitian ini maka diharapkan siswa memiliki keterampilan membaca yang baik karena dengan membaca sangat berpengaruh terhadap keterampilan menulis yang dimiliki.

Gerakan Literasi Sekolah (GLS) merupakan gerakan literasi yang aktiitasnya banyak dilakukan di sekolah dengan melibatkan siswa, pendidikan dan tenaga kependidikan, serta orang tua. GLS dilakukan dengan menampilkan praktik baik tentang literasi dan menjadikannya sebagai kebiasaan serta budaya di lingkungan sekolah. Literasi juga dapat diintegrasikan dalam kegiatan belajar mengajar di sekolah sehingga menjadi bagian tiak terpisahkan dari semua rangkaian kegiatan siswa dan pendidik, baik di dalam maupun di luar kelas (Atmazaki et al., 2017:28).

$$
\text { Berdasarkan observasi yang }
$$

dilakukan peneliti pada tanggal 10 Agustus sampai dengan 12 Agustus 2021 diperoleh beberapa informasi dari sekolah, terutama Guru Kelas V. Yang mana sebenarnya Kegiatan Literasi sudah dilakukan dan juga masuk ke dalam Proses Pembelajaran Tematik. Akan tetapi penerapannya kadang tidak berjalan secara maksimal, terlebih dimusim Pandemi. Dikarenakan terbatasnya fasilitas yang ada serta kurang fokusnya hari Kegiatan Literasi dan dilema Daring peserta didik yang disebabkan oleh banyak faktor.

Merujuk pada penelitian sebelumnya tentang "Keefektifan Sabtu Literasi Untuk Meningkatkan Kemampuan Menulis Siswa SDN 3 Banjar Jawa" yang menyatakan bahwa Sabtu Literasi dapat meningkatkan kemampuan menulis siswa (Tantri \& Dewantara, 2017:1). Sebagai rujukan lainnya yaitu penelitian Safitri (2009) dalam Judul "Peran Literasi Terhadap Kemampuan Menulis Karangan Siswa Pada Mata Pelajaran Bahasalndonesia Kelas V Di MI Hijriyah II Palembang dan Puspitaningrum \& Nuryanto (2019) tentang "Pengaruh Literasi dan Kaidah Ejaan Terhadap Kemampuan Menulis Narasi Siswa Kelas V" yang keduanya menyatakan bahwa literasi memiliki peran dalam menunjang kemampuan menulis peserta didik.

Berkaitan dengan hal tersebut, tujuan dalam penelitian ini adalah untuk mengetahui bagaimana kegiatan Sabtu Literasi dilaksanakan, terutama terhadap keterampilan menulis teks narasi siswa 
kelas V SD Muhammadiyah 3 Surabaya di masa pandemi covid-19. Selanjutnya dapat dijadikan referensi Sekolah Dasar lain untuk tetap membudayakan literasi meskipun dalam masa pandemi.

\section{Metode Penelitian}

Pendekatan yang digunakan dalam penelitian ini adalah deskriptif kualitatif. Yang akan menggambarkan keadaan yang sebenarnya di lapangan, termasuk analisis sabtu literasi pada siswa kelas V SD Muhammadiyah 3 Surabaya dalam menulis teks narasi dimasa pandemi.

Teknik pengumpulan data yang digunakan dalam penelitian ini adalah metode observasi, wawancara tak berstruktur, dan dokumentasi

Menurut Guba dan Lincoln, pengamatan atau observasi dalam pengumpulan data dilakukan karena; (1) Teknik pengamatan didasarkan atas pengamatan langsung, (2) Teknik pengamatan memungkinkan melihat, mengamati, dan mencatat kejadian atau perilaku yang sebenarnya, pengamatan memungkinkan mencatat peristiwa dalam situasi yang berkaitan dengan pengetahuan proporsional maupun yang langsung diperoleh dari data, (4) dapat digunakan untuk menguji kebenaran data yang meragukan, (5) memungkin akan peneliti mampu memahami situasi yang rumit, (6) dapat menjadi alat yang bermanfaat bagi kasuskasus tertentu yang tidak memungkinkan dilakukan dengan teknik lain (Hayati, 2012:87).

$$
\text { Peneliti berperan sebagai }
$$
pengamat dan turut serta ketika proses kegiatan sabtu literasi berlangsung. Dengan demikian, peneliti memilih teknik observasi jenis partisipan untuk mengamati bagaiamana kegiatan sabtu literasi dilaksanakan.

Teknik wawancara, merupakan teknik penggalian data melalui percakapan yang dilakukan dengan maksud tertentu, dari dua pihak atau lebih. Pewawancara (interviewer) adalah orang yang memberikan pertanyaan, sedangkan orang yang diwawancarai (interviewee) berperan sebagai narasumber yang akan memberikan jawaban atas pertanyaan yang disampaikan (Nugrahani, 2014:125). Peneliti menggunakan wawancara tak berstruktur, yang ditujukan kepada pustakawan selaku mitra literasi sekolah, guru kelas $\mathrm{V}$ dan siswa kelas $\mathrm{V}$. Yang bertujuan untuk lebih bersifat personal dan memungkinkan peneliti menggali informasi sebanyak yang diperlukan serta digunakan sebagai triangulasi sumber dan metode untuk memperoleh validitas data. 
Dokumentasi merupakan data yang penunjang dan lebih mengarah pada bukti konkret, dengan ini peneliti hanya menganalisis dokumen-dokumen yang mendukung penelitian (Sugiyono, 2013:226). Sebagai pendukung penelitian, peneliti memilih dokumentasi berupa gambar dan dokumen yang berkaitan dengan kegiatan Sabtu Literasi tersebut.

Teknik analisis data yang digunakan dalam penelitian ini sesuai dengan Model Miles dan Huberman. Dalam Teknik tersebut ada tiga (3) komponen utama, yaitu :

1. Reduksi Data

Suatu proses pemilihan, pemusatan perhatian pada penyederhanaan,pengabstrakan, dan transformasi data kasar yang muncul dari catatancatatan dilapangan atau dalam hal ini memilih hal-hal pokok sesuai dengan fokus penelitian.

2. Penyajian Data

Setelah reduksi data dilakukan, maka hal berikutnya yaitu penyajian data. Yaitu upaya untuk menyajikan informasi yang tersusun secara sistematis yang memungkinkan dapat ditarik suatu kesimpulan dan tindakan.

3. Penarikan Simpulan.

Penarikan Simpulan ini dapat dilakukan berdasarkan data yang diperoleh dilapangan dan menyajikan dalam bentuk kata-kata secara deksriptip kualitatif. Dan perlu diverifikasi atau ditinjau ulang meskipun secara singkat oleh Peneliti terutama selama menulis agar dapat dipertanggung jawabkan kebenarannya (Tantri \& Dewantara, 2017:2).

\section{Hasil dan Pembahasan}

Secara istilah pengertian literasi adalah kemampuan menulis dan membaca (KBBI Daring, n.d.)dan ditegaskan oleh (Rinawati et al., 2020:1) bahwa keterampilan membaca sangat erat hubungannya dengan keterampilan menulis, semakin banyak dan baik dalam membaca maka karya tertulisnya juga semakin baik. Dengan demikian, memang sudah seharusnya kegiatan membaca dan menulis saling berkaitan. Sehingga dalam kegiatan literasi tidak hanya membaca saja yang ditekankan akan tetapi menulis juga dapat diintegrasikan. Menurut Atmazaki et al. (2017:3) menyatakan bahwa revolusi digital telah memberikan kemudahan dan kenyamaan bagi kehidupan manusia sehingga mampu mengubah sendi - sendi kehidupan, kebudayaaan, kemasyarakatan. Sehingga kegiatan literasi yang semula pelaksanaannya hanya 
disekolah, saat ini dapat dilaksanakan dimana saja dengan cara daring.

Kegiatan sabtu literasi yang dilaksanakan SD Muhammadiyah 3 Surabaya adalah hari Sabtu, secara daring dengan memanfaatkan Zoom Meeting dan Whatsapp Group (WAG) yang dipandu oleh pustakawan dan guru.

Dalam persiapan pelaksanaannya, pustakawan dan guru harus mempersiapkan gadget atau gawai berupa handphone android dan laptop yang dilengkapi paket data atau akses wifi. Pustakawan diharuskan menjadi anggota disetiap akun grup kelas masingmasing. Selanjutnya, pustakawan mempersiapkan buku bacaan teks narasi dalam bentuk portable document format (pdf), sesuai dengan materi sabtu literasi.

Dalam pelaksanaan kegiatan sabtu literasi, kelas 5 ABC digabung menjadi satu jenjang untuk efisiensi waktu yang dipakai. Guru dan pustakawan dimulai dengan online terlebih dahulu melalui WAG dan Zoom Meeting, yang mana informasi link dishare sehari sebelum pelaksanaan. Ketika siswa mulai banyak bergabung, guru dan pustakawan menyapa dan mengajak mereka untuk berdo'a sebelum kegiatan sabtu literasi dimulai, dilanjutkan dengan mempersilahkan siswa mengisi presensi yang telah disiapkan dalam bentuk google form yang telah dishare pada WAG. Guru dan pustakawan menjelaskan secara singkat tentang kegiatan yang akan dilaksanakan pada hari tersebut, selanjutnya membagikan teks narasi "Teman yang Baik" berbentuk pdf melalui WAG. Setelah itu siswa diminta untuk membaca senyap teks narasi tersebut dirumah masing-masing dengan pantauan guru dan pustakawan melalui layar monitor, yang sebelumnya diinformasikan untuk membuka kamera gadget atau gawai. Sesekali memang tampak tidak kondusif dikarenakan ada aktivitas lain yang terjadi dibelakang siswa dan microphone yang tidak dibisukan ketika daring, akan tetapi terlihat kondusif kembali ketika admin Zoom Meeting mematikan suara peserta. Dilanjutkan dengan pembacaan secara singkat teks narasi "Teman yang Baik" oleh guru. Siswa begitu terlihat antusias menyimak cerita dan itu terbukti ketika durasi Zoom Meeting telah habis, mereka log in kembali untuk menyimak cerita yang dibacakan guru.

Pada kegiatan penutup guru dan pustakawan meminta siswa untuk menulis atau menceritakan kembali tentang teks narasi yang telah dibaca, agar dapat diketahui feedback atau output kegiatan sabtu literasi pada hari tersebut khususnya teks narasi serta diakhri dengan berdo'a.

Kegiatan sabtu literasi secara daring di masa pandemi ini dilaksanakan selama 
45 menit, terdiri dari persiapan, pelaksanaan, dan penutup. Dengan estimasi tugas/laporan yang dikumpulkan 2-3 jam setelah Zoom Meeting. Durasi ditentukan dengan mempertimbangkan kendala teknis yang mungkin terjadi pada siswa.

Dari hasil observasi terlihat guru dan pustakawan sangat bersinergi dalam memandu kegiatan tersebut, sehingga siswa yang mengikuti dapat menyimak dan mengikuti instruksi yang diberikan, walaupun ada kendala yang ditemui dilapangan, seperti tidak keseluruhan siswa yang dapat mengikuti kegiatan sabtu literasi. Beberapa kendalanya adalah tidak bisa log in Zoom Meeting, serta terbatasnya kuota data dan gawai yang dimiliki. Akan tetapi siswa yang mengikuti sudah melebihi dari sebagian jumlah seluruh siswa kelas 5 ABC yakni 47 siswa dari 88 siswa, dan ini sudah dinyatakan presensi efektif dimasa pandemi menurut salah satu guru Kelas V.

Dalam laporan tugas menulis teks narasi siswa yang terkumpul, diproleh data sebagai berikut:

1) 25 siswa memperoleh skor antara $16-20$

2) 22 siswa memperoleh skor antara $11-15$

3) 0 siswa memperoleh skor 6-10

4) 0 siswa memperoleh skor 1-5 *skala/maksimal skor: 20

Sehingga dari data tersebut dapat ditarik kesimpulan bahwa seluruh siswa sudah memiliki keterampilan yang bagus dalam menulis teks narasi, dan mayoritas dari mereka memilki keterampilan diatas ratarata.

Dari hasil wawancara yang dilakukan berkaitan dengan teks narasi, diantaranya sebagai berikut. Menurut Guru Kelas V, bahwa sabtu literasi sangat efektif dalam menambah pengetahuan dan dalam pem-bendaharaan kata terlebih untuk teks narasi, sehingga dapat melatih siswa untuk bercerita runtut sehingga nantinya mereka akan dengan mudah untuk membuat Cerita Pendek (Cerpen).

Pustakawan menyatakan bahwa sabtu literasi mempunyai banyak manfaat terutama bagi siswa, diantaranya memperkaya pengetahuan kosa kata, kreativitas dalam menulis dan menyusun kata, menambah wawasan serta menambah daya ingat melalui membaca, dan keterampilan siswa yang sudah bagus dalam menulis teks narasi dengan menggunakan bahasa sendiri.

Sedangkan menurut siswa yang diwawancarai secara random yang merupakan perwakilan kelas, menyatakan bahwa kegiatan Sabtu Literasi adalah kegiatan menyenangkan dan efektif dalam menambah 
pengetahuan atau wawasan, dan banyak dari mereka sudah faham tentang pengertian literasi dan teks narasi. Adapun kendala ketika pelaksanaan Sabtu Literasi terhadap menulis teks narasi siswa adalah, terbatasnya waktu membaca, mencari tema bacaam dan kata-kata yang penting dari teks. Tapi kendala tersebut dapat dengan mudah diatasi oleh mereka dengan mencari solusi secara mandiri, antara lain mempercepat waktu membaca, dan memahami kembali isi bacaan dengan membaca kembali teks. Demikian Kegiatan Sabtu Literasi terhadap keterampilan menulis siswa kelas $\mathrm{V} S \mathrm{D}$ Muhammadiyah 3 Surabaya yang dilaksanakan secara daring.

\section{Kesimpulan}

Kegiatan Sabtu Literasi yang telah dilaksanakan oleh siswa kelas V SD Muhammadiyah 3 Surabaya tersebut sangat disukai siswa, dan sangat bermanfaat sekali, terutama dalam membantu melatih siswa untuk keterampilan menulis teks narasi. Kegiatan tersebut dikemas secara Daring dengan durasi selama 45 menit, dan estimasi penulisan laporan teks narasi selama 2-3 jam setelah Daring selesai. Meskipun banyak kendala yang dijumpai di lapangan, seperti terbatasnya gawai/paket data yang dimiliki hingga gangguan teknis saat proses Daring, ini tidak menyurutkan minat siswa untuk mengikuti kegiatan tersebut. Dalam penulisan laporan yang berkaitan dengan teks narasi, sebagian besar dari mereka sudah memiliki kemampuan diatas ratarata, sehingga dengan adanya kegiatan tersebut diharapkan semua siswa nantinya mampu meningkatkan keterampilan menulis terlebih bagi siswa yang tidak hadir pada kegiatan Daring tersebut. Dengan demikian kegiatan Sabtu Literasi di masa pandemi ini, sangat layak dan dapat dijadikan program sekolah terutama terhadap keterampilan menulis siswa kelas $\mathrm{V}$ meskipun melalui daring.

\section{Daftar Pustaka}

Atmazaki, Ali, N. B. V., Muldian, W., Miftahussururi, Hanifah, N., Nento, M. N., \& Akbari, Q. S. (2017). Panduan Gerakan Literasi Nasional (L. A. Mayani, M. Aziz, \& Munafsin, Eds.). Kemernterian Pendidikan dan Kebudayaan.

Hayati, L. (2012). Pengembangan Budaya Belajar dan Dampaknya Terhadap Mutu Layanan Pembelajaran Di Sekolah Alam. 
KBBI Daring. (n.d.). kbbi.kemdikbud.go.id.

Nugrahani, F. (2014). Metode Penelitian Kualitatif dalam Penelitian Pendidikan Bahasa.

Puspitaningrum, A. D., \& Nuryanto, S. (2019). Pengaruh Literasi dan Kaidah Ejaan Terhadap Kemampuan Menulis Narasi Siswa Kelas V. Joyful Learning Journal, 8(4).

Rinawati, A., Mirnawati, L. B., \& Setiawan, F. (2020). Analisis Hubungan Keterampilan Membaca dengan Keterampilan Menulis Siswa Sekolah Dasar. Education Journal : Journal Education Research and Development, 4(2).

Safitri, T. (2009). Peran Literasi Terhadap Kemampuan Menulis Karangan Siswa Pada Mata Pelajaran Bahasa Indonesia Kelas V Di Mi Hijriyah II Palembang.

Sugiyono. (2013). Metode penelitian Kuantitatif, Kualitatif \& R\&D. Alfabeta.

Sunarti. (2020). Keterampilan Membaca dapat Meningkatkan Penguasaan Kosakata Siswa.

Https://Radarsemarang.Jawapos.Com/Rubrik/UntukmuGuruku/2021/07/27/Keterampilan-Membaca-Dapat-Meningkatkan-PenguasaanKosakata-Siswa/.

Tantri, A. A. S., \& Dewantara, P. M. (2017). Keefektifan Sabtu Literasi untuk Meningkatkan Kemampuan Menulis Siswa SDN 3 Banjar Jawa. Seminar Nasional Riset Inovatif 2017.

Undang-Undang Indonesia Nomor 20 Tahun 2003 Tentang Sistem Pendidikan Nasional. 